\title{
Physiology in Talisia esculenta seedlings under irrigation with saline water on substrate with hydrogel
}

\section{Fisiologia em mudas de Talisia esculenta sob irrigações com água salina em substrato com hidrogel}

\begin{abstract}
Francisco Thiago Coelho Bezerra ${ }^{1 *}$; Marlene Alexandrina Ferreira Bezerra ${ }^{2}$; Raiff Ramos Almeida Nascimento ${ }^{3}$; Walter Esfrain Pereira4; Carlos Jardel Andrade

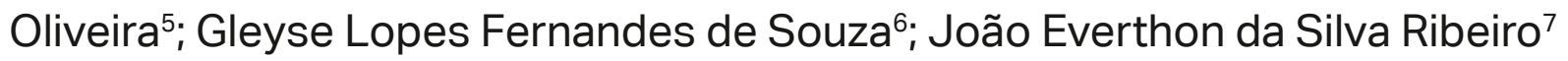

Highlights

The Talisia esculenta seedlings are considered sensitive to salinity.

Salinity reduces seedling emergence and alters young plant photosynthesis.

Irrigation with water above $1 \mathrm{dS} \mathrm{m}^{-1}$ is not recommended for $T$. esculenta seedlings.

Higher irrigation frequencies mitigate salt stress.

Larger containers provide better conditions for seedlings.

\begin{abstract}
Salinity interferes in the physiology of seedlings from germination and seedling emergence, so it is necessary to adopt measures to mitigate its effects. The objectives of this research were to evaluate irrigation frequency, saline water, polymer, and container volume in the emergence and physiology of Talisia esculenta (A. St.-Hil.) Radlk. The treatments were obtained from the combination of polymer doses $(0.0 ; 0.2$; 0.6 ; 1.0; and $\left.1.2 \mathrm{~g} \mathrm{dm}^{-3}\right)$, electrical conductivities of the irrigation water $\left(0.3 ; 1,1 ; 2.7 ; 4.3\right.$; and $\left.5.0 \mathrm{dS} \mathrm{m}^{-1}\right)$, and irrigation frequencies (daily and alternate), plus two additional treatments to assess the volume of the container. A randomized block design was used. Emergence and leaf indices of chlorophyll, fluorescence, and gas exchange were analyzed 100 days after sowing. The increase in electrical conductivity reduced and delayed seedling emergence. Decreasing irrigation frequency reduced the chlorophyll $b$ index, stomatal conductance, transpiration, net $\mathrm{CO}_{2}$ assimilation, and carboxylation efficiency. The magnitude of the effects

1 Dr. Researcher, Scientific and Regional Development Scholarship - CNPq - by the Postgraduate Program in Agronomy, Universidade Federal da Paraíba, UFPB, Areia, PB, Brazil. E-mail: bezerra_ftc@yahoo.com.br

$2 \mathrm{Dr}^{\mathrm{a}}$ Researcher, National Postdoctoral Program Scholarship - CAPES - by the Postgraduate Program in Agronomy, UFPB, Areia, PB, Brazil. E-mail: marlene_agro@hotmail.com

${ }^{3}$ Student of the Master's Course of the Postgraduate Program in Agronomy, UFPB, Areia, PB, Brazil. E-mail: raifframosufpb@gmail.com

${ }^{4}$ Prof. Dr., Postgraduate Program in Agronomy, UFPB, Areia, PB, Brazil. E-mail: walterufpb@gmail.com

${ }^{5}$ Student of the Doctoral Course of the Postgraduate Program in Agronomy, UFPB, Areia, PB, Brazil. E-mail:jardeloros@ hotmail.com

${ }^{6}$ M.e in Agronomy, Postgraduate Program in Agronomy, UFPB, Areia, PB, Brazil. E-mail: gleyselfs@hotmail.com

7 Prof. Dr., Universidade Estadual do Maranhão, UEMA, Itapecuru Mirim, MA, Brazil. E-mail: j.everthon@hotmail.com

* Author for correspondence
\end{abstract}

Received: July 24, 2021 - Approved: Dec. 08, 2021 
of electrical conductivity of water and polymer were associated with the frequency of irrigation. However, both salinity and polymer reduced practically all physiological variables. The reduction in container volume also affected the physiology of the seedlings, with more effects when irrigated on alternate days. The $T$. esculenta seedlings are considered sensitive to salinity, should be irrigated daily with water with less electrical conductivity than $1.0 \mathrm{dS} \mathrm{m}^{-1}$, as well as higher capacity containers used ( $\left.0.75 \mathrm{vs} 1.30 \mathrm{dm}^{3}\right)$.

Key words: Container volume. Gas exchange. Salt stress. Seedling emergence. Water-retaining polymer.

\section{Resumo}

A salinidade interfere na fisiologia das mudas desde a germinação e emergência das plântulas, por isso, é necessário adotar medidas que mitiguem seus efeitos. Os objetivos com esta pesquisa foi avaliar frequências de irrigação, salina da água, polímero e volume de recipiente na emergência e fisiologia de Talisia esculenta (A. St.-Hil.) Radlk. Os tratamentos foram obtidos da combinação entre doses de polímero $\left(0,0 ; 0,2 ; 0,6 ; 1,0 \mathrm{e} ; 1,2 \mathrm{~g} \mathrm{dm}^{-3}\right)$, condutividades elétricas da água de irrigação $(0,3 ; 1,1 ; 2,7 ; 4,3 \mathrm{e} ; 5,0 \mathrm{dS}$ $\mathrm{m}^{-1}$ ) e frequências de irrigação (diária e alternada), mais dois tratamentos adicionais para avaliar o volume do recipiente. Utilizou-se o delineamento de blocos casualizados. Foram analisados a emergência e aos 100 dias após a semeadura os índices foliares de clorofila, fluorescência e trocas gasosas. O aumento da condutividade elétrica reduziu e atrasou a emergência das plântulas. A diminuição da frequência de irrigação reduziu o índice de clorofila $b$, condutância estomática, transpiração, assimilação líquida de $\mathrm{CO}_{2}$ e a eficiência carboxilação. A magnitude dos efeitos da condutividade elétrica da água e do polímero estiveram associados com a frequência de irrigação. Entretanto, tanto a salinidade quanto o polímero reduziram praticamente todas as variáveis fisiológicas. A redução no volume do recipiente também afetou a fisiologia das mudas, com mais efeitos ao se irrigar em dias alternados. As mudas de $T$. esculenta são consideradas sensíveis à salinidade, devendo-se irrigar diariamente com água com condutividade elétrica

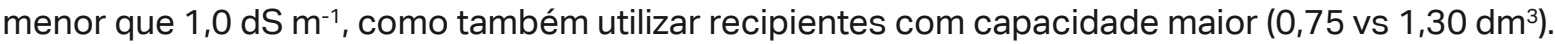

Palavras-chave: Volume de recipiente. Trocas gasosas. Estresse salino. Emergência de muda. Polímero hidroretentor.

\section{Introduction}

Salt stress reduces the growth and quality of seedlings from emergence (Bezerra, Pereira, Bezerra, Cavalcante, \& Medeiros, 2014; F. S. Oliveira et al., 2016), for example, in Annona squamosa L. (A. R. Silva et al., 2018a,b), Passiflora edulis Sims (Bezerra et al., 2019), Tamarindus indica L. (Lima et al., 2018), Artocarpus heterophyllus Lam. (Oliveira et al., 2017) as well as in Talisia esculenta (A. St.Hil.) Radlk. (Melo et al., 2017). The increase in soluble salts, in addition to reducing the water potential and consequently hindering water absorption, causes specific toxic effects of the ions (Taiz, Zeiger, Møller, \& Murphy, 2017) and, in excess, can change the concentration of chlorophyll (Rahneshan, Nasibi, \& Moghadam, 2018; Shin, Bhandari, Cho, \& Lee, 2020) and quantum kinetics (Baker, 2008), limiting the energy flow for $\mathrm{CO}_{2}$ assimilation; as well as gas exchange $(\mathrm{H}$. H. C. Nascimento, Santos, Freira, Silva, \& Nogueira, 2015) and biochemical reactions in chloroplasts (Cruz, 
Coelho, Coelho, \& Santos, 2017) resulting in allometric and morphophysiological changes (E. C. Nascimento et al., 2020).

It is necessary to understand the physiological behavior of $T$. esculenta seedlings to salinity, as the effects of this factor are associated with both the species and the growth/development phase, and thus establish strategies that enable production in regions with salinity problems in water from irrigation. $T$. esculenta is cultivated for consumption of fruits, bark, leaves and wood, besides planting in degraded areas (Guarim, Guarim, \& Nascimento, 2003). Research that seeks to understand physiological responses of fruit trees to salt stress, which are scarce in the literature, associated with measures that mitigate the effects of salts are essential for the production of quality seedlings contributing to the formation and longevity of the orchard.

In recent years, water-retaining polymer has been used with the aim, in most cases, to resolve problems related to water availability. However, this input can interfere in the emergence of seedlings (Fagundes et al., 2014) and in the physiology of young plants (Felippe et al., 2019) by interfering mainly in the water dynamics. Water-retaining polymer, in addition to allowing an increase in the interval between irrigations, has the potential to reduce nutrient losses due to leaching (Navroski et al., 2015). However, not only the depth but also the frequency of irrigation can affect the performance of seedlings (A. R. Silva et al., 2018a,b; E. C. Nascimento et al., 2020) if poorly planned, and can economically burden the agricultural activity by using energy and/ or hand labor.
The adequacy of the volume of containers is also a relevant factor impacting the production of seedlings (A. R. Silva et al., 2018a,b; E. C. Nascimento et al., 2020) as the root restriction determined by the smaller volume of container can change the fluorescence and gas exchange (Ouma, 2007; Dias et al., 2018). However, Campany, Medlyn and Duursma (2017) do not relate the lower growth of seedlings under root restriction to the reduction in carbon dioxide assimilation, even though they obtained smaller seedlings. It is therefore necessary to determine the smallest container volume that does not affect the formation and quality of seedlings to reduce production and transport costs.

Therefore, this research was developed to evaluate the effects of irrigation frequency, electrical conductivity of saline water, water-retaining polymer, and container volume on the physiology of $T$. esculenta (A. St.-Hil.) Radlk seedlings.

\section{Material and Methods}

\section{Experiment location}

The research was carried out in greenhouse $\left(6^{\circ} 58^{\prime} 10.9^{\prime \prime}\right.$ South; $35^{\circ} 42^{\prime} 59.1^{\prime \prime}$ West and; $536 \mathrm{~m}$ elevation above sea level) of the Department of Soils and Rural Engineering, of the Center for Agricultural Sciences, of the University Federal da Paraíba, municipality of Areia, state of Paraíba, Brazil.

\section{Treatments and design}

The treatments were obtained from the arrangement between doses of the 
Hydroplan-EB/HyA water-retaining polymer $\left(0.0 ; 0.2 ; 0.6 ; 1.0\right.$; and $1.2 \mathrm{~g} \mathrm{dm}^{-3}$ ) and the electrical conductivities of the irrigation water (0.3; $1.1 ; 2.7 ; 4.3$; and $\left.5.0 \mathrm{dS} \mathrm{m}^{-1}\right)$, following the scheme $2^{2}+2 \times 2+1$ of the Box's Central Composite matrix (Montgomery, 2017), combined in a factorial with two irrigation frequencies (daily and alternate), plus two additional treatments to observe the effect of container volume (Table 1). The experimental design used was randomized blocks with four replications and the experimental unit consisted of four containers.

\section{Substrate preparation}

The substrate used was a mixture of soil, sand, and cattle manure in the proportion of 3: 2: 1 respectively. Soil material was taken from the $0-20 \mathrm{~cm}$ deep layer of a Red-Yellow Latosol profile. Cattle manure was obtained from a cattle housing unit. Each component of the substrate, after properly drying in air and in the shade, was passed through a 4-mm mesh sieve and then homogenized.

A substrate sample was collected and analyzed, presenting the following attributes in the cation exchange complex: 5.9 of $\mathrm{pH}$; $0.23,0.88,1.74,1.28,4.13,9.47$, and 13.60 $\mathrm{cmol}_{\mathrm{c}} \mathrm{dm}^{-3}$ of $\mathrm{Na}^{+}, \mathrm{K}^{+}, \mathrm{Ca}^{2+}, \mathrm{Mg}^{2+}$, sum of bases, $\mathrm{H}^{+}+\mathrm{Al}^{3+}$, cation exchange capacity, respectively; $30.3 \%$ of base saturation;
$45.0 \mathrm{mg} \mathrm{dm}^{-3}$ of phosphorus; $2.43 \%$ of

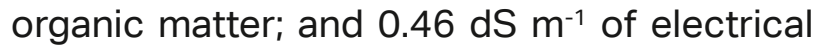
conductivity in the soil-water suspension. The saturation paste extract was determined to have a $\mathrm{pH}$ of 5.90; electrical conductivity of $1.97 \mathrm{dS} \mathrm{m}^{-1} ; 15.25,0.00,2.80,4.62,8.88$, $5.46,5.13, \mathrm{mmol}_{\mathrm{c}} \mathrm{L}^{-1}$ of $\mathrm{Cl}^{-1}, \mathrm{CO}_{3}^{2-}, \mathrm{HCO}_{3}^{-}$, $\mathrm{Ca}^{2+}, \mathrm{Mg}^{2+}, \mathrm{K}^{+}, \mathrm{Na}^{+}$, respectively; and sodium adsorption ratio of $1.97\left(\mathrm{mmol} \mathrm{L} \mathrm{L}^{-1}\right)^{0,5}$. As regards texture and grain size, $68.67 \%$ sand, $18.17 \%$ silt, and $13.16 \%$ clay were obtained; with 1.35 and $2.64 \mathrm{~g} \mathrm{~cm}^{-3}$ of soil and particle density, respectively; porosity was $48.86 \%$; and humidity $15.81 \%$ and $8.22 \%$ under the respective tensions of 0.033 and $1.5 \mathrm{MPa}$.

In the preparation of the substrate, the phosphorus and nitrogen contents were increased to 300 and $100 \mathrm{mg} \mathrm{kg}^{-1}$ (Novais, Neves, \& Barros, 1991), respectively and at 60 and 85 days after sowing, $200 \mathrm{mg} \mathrm{dm}^{-3}$ of nitrogen was applied. The sources of mineral fertilizers were urea $(45 \% \mathrm{~N})$ and monoammonium phosphate $\left(52 \% \quad \mathrm{P}_{2} \mathrm{O}_{5^{\prime}}\right.$ $11 \% \mathrm{~N})$. The water-retaining polymer was incorporated into the dry substrate, prior to filling the containers, according to the treatments applied (Table 1). Before mixing, each $1 \mathrm{~g}$ of dry polymer was hydrated with $49 \mathrm{~g}$ of water. After filling the containers, irrigation was carried out in order to moisten the substrate, in order to accommodate the substrate particles, for sowing. 
Table 1

Arrangement between the factors (HyA - polymer; ECw - electrical conductivity of the irrigation water; FI - irrigation frequency; and CtV - container volume) used in the experiment

\begin{tabular}{|c|c|c|c|c|c|c|}
\hline \multirow{2}{*}{ Treat. $^{1}$} & \multicolumn{2}{|c|}{ Levels $^{2}$} & \multicolumn{2}{|c|}{ Doses/Concentrations } & \multirow{2}{*}{ IF } & \multirow{2}{*}{$\begin{array}{c}\mathrm{CtV} \\
\left(\mathrm{dm}^{3}\right)\end{array}$} \\
\hline & HyA & ECiw & $\mathrm{HyA}\left(\mathrm{g} \mathrm{dm}^{-3}\right)$ & ECiw $\left(\mathrm{dS} \mathrm{m}^{-1}\right)$ & & \\
\hline 1 & -1 & -1 & 0.2 & 1.1 & Daily & 1.30 \\
\hline 2 & -1 & 1 & 0.2 & 4.3 & Daily & 1.30 \\
\hline 3 & 1 & -1 & 1.0 & 1.1 & Daily & 1.30 \\
\hline 4 & 1 & 1 & 1.0 & 4.3 & Daily & 1.30 \\
\hline 5 & $-1.41(-\alpha)^{2}$ & 0 & 0.0 & 2.7 & Daily & 1.30 \\
\hline 6 & $1.41(\alpha)$ & 0 & 1.2 & 2.7 & Daily & 1.30 \\
\hline 7 & 0 & $-1.41(-\alpha)$ & 0.6 & 0.3 & Daily & 1.30 \\
\hline 8 & 0 & $1.41(\alpha)$ & 0.6 & 5.0 & Daily & 1.30 \\
\hline 9 & 0 & 0 & 0.6 & 2.7 & Daily & 1.30 \\
\hline 10 & -1 & -1 & 0.2 & 1.1 & Alternate & 1.30 \\
\hline 11 & -1 & 1 & 0.2 & 4.3 & Alternate & 1.30 \\
\hline 12 & 1 & -1 & 1.0 & 1.1 & Alternate & 1.30 \\
\hline 13 & 1 & 1 & 1.0 & 4.3 & Alternate & 1.30 \\
\hline 14 & $-1.41(-\alpha)$ & 0 & 0.0 & 2.7 & Alternate & 1.30 \\
\hline 15 & $1.41(\alpha)$ & 0 & 1.2 & 2.7 & Alternate & 1.30 \\
\hline 16 & 0 & $-1.41(-\alpha)$ & 0.6 & 0.3 & Alternate & 1.30 \\
\hline 17 & 0 & $1.41(\alpha)$ & 0.6 & 5.0 & Alternate & 1.30 \\
\hline 18 & 0 & 0 & 0.6 & 2.7 & Alternate & 1.30 \\
\hline 19 & 0 & 0 & 0.6 & 2.7 & Daily & 0.75 \\
\hline 20 & 0 & 0 & 0.6 & 2.7 & Alternate & 0.75 \\
\hline
\end{tabular}

${ }^{1}$ Number of treatments for each arrangement between polymer doses and electrical conductivity of the irrigation water $=2^{\mathrm{k}}+2 \mathrm{k}+1\left(\mathrm{k}=2\right.$, number of factors) $\therefore 2^{2}+2 \times 2+1=9 ;{ }^{2}$ Levels established according to the Box central matrix; ${ }^{3} \alpha=$ 1.41 .

Obtaining seeds and conducting the experiment

The fruits of $T$. esculenta were purchased at the local market. The seeds were extracted from the fruits manually, placed in water for 24 hours for fermentation of the pulp, and then washed in running water, removing the remaining pulp. After pulping, the seeds were put to dry in the shade for 24 hours and then sown directly in the containers.
Sowing was carried out by placing two seeds per container at a depth of approximately $2.5 \mathrm{~cm}$. Irrigation water was prepared by adding sodium $\left(\mathrm{Na}^{+}\right)$, calcium $\left(\mathrm{Ca}^{2+}\right)$, and magnesium $\left(\mathrm{Mg}^{2+}\right)$ ions to the supply water $\left(0.3 \mathrm{dS} \mathrm{m}^{-1}\right)$ in a ratio of 5:2:1 (L. G. A. Silva, Gheyi, \& Medeiros, 1999) on a mass basis, respectively in the form of chloride. This proportion was obtained from the dissolution of $635.5 \mathrm{~g}$ of sodium chloride ( $\mathrm{NaCl}), 367.0$ of calcium chloride dihydrate $\left(\mathrm{CaCl}_{2} \cdot 2 \mathrm{H}_{2} \mathrm{O}\right)$, and 
$418.0 \mathrm{~g}$ of magnesium chloride hexahydrate $\left(\mathrm{MgCl}_{2} \cdot 6 \mathrm{H}_{2} \mathrm{O}\right)$ in $100 \mathrm{~L}$ of water, considering the stock solution, with an electrical conductivity of approximately $22 \mathrm{dS} \mathrm{m}^{-1}$. This stock solution was diluted in supply water, with a conductivity of $0.3 \mathrm{dS} \mathrm{m}^{-1}$, to obtain the levels of conductivity studied, which were measured with a portable conductivity meter. In irrigation with alternate frequency, started after thinning carried out 42 days after sowing, the equivalent of $70 \%$ of the volume applied daily was applied. A daily blade was applied to keep the substrate close to field capacity, observing the beginning of drainage.

\section{Variables analyzed}

The emergence of $T$. esculenta seedlings started 12 days after sowing and, from that date, was evaluated daily for 28 days. The emergence speed index - ESI (Maguire, 1962) was also calculated using the following expression:

$$
E S I=\frac{E_{1}}{N_{1}}+\frac{E_{2}}{N_{2}}+\cdots+\frac{E_{n}}{n}
$$

Where:

$E_{1}, E_{2}, E_{n}$ - number of seedlings emerged in the first, second, ..., and last evaluation; N1, N2, Nn - number of days from sowing to first, second, ..., and the last count.

The analyzed variables, 100 days after sowing, were: chlorophylls $a$ and $b$, ratio $a / b$, and total chlorophyll indices with ClorofiLOG model CFL 1030 da Falker ${ }^{\circledR}$; initial (Fo), maximum (Fm), and variable (Fv) fluorescence of chlorophyll a relationship between photochemical and non-photochemical processes (Fv/Fo), and quantum efficiency of photosystem II (Fv/Fm) with portable fluorometer model OS -30p of Opti-Sciences ${ }^{\circledR}$; and gas exchange - leaf temperature (Tleaf, ${ }^{\circ} \mathrm{C}$ ), stomatal conductance (gs, mol $\mathrm{H}_{2} \mathrm{O} \mathrm{m}{ }^{-2}$ $\mathrm{s}^{-1}$ ), internal carbon dioxide concentration (ci, $\mu \mathrm{mol} \mathrm{CO}_{2} \mathrm{~mol}^{-1}$ of air), relationship between internal and environmental carbon ( $c_{i} /$ $\left.C_{e}\right)$, transpiration $\left(E, m m o l ~ H_{2} O m^{-2} s^{-1}\right)$, net assimilation of carbon dioxide $\left(\mathrm{A}, \mu \mathrm{mol} \mathrm{CO}_{2}\right.$ $\mathrm{m}^{-2} \mathrm{~s}^{-1}$ ), water use efficiency (WUE, $\mu \mathrm{mol} \mathrm{CO}_{2}$ $\mathrm{mol}^{-1} \mathrm{H}_{2} \mathrm{O}$ ), and instantaneous carboxylation efficiency ( $\mathrm{iCE}, \mathrm{mol} \mathrm{CO}_{2} \mathrm{~m}^{-2} \mathrm{~s}^{-1}$ ) - with gas analyzer in infrared phase (Irga), model LCproSD from BioScientific ${ }^{\circledR}$, under irradiance of $1,200 \mu \mathrm{mol}$ photons $\mathrm{m}^{-2} \mathrm{~s}^{-1}$.

\section{Statistical analysis}

The daily emergency data were fitted to non-linear regression of the sigmoidal type, logistic model, as described below, with estimates of the parameters evaluated later as a function of the treatments:

$$
\hat{\mathrm{y}}=\frac{A}{1+\exp \frac{-(D A S-X o)}{B}} ; R_{a j .}^{2}=R^{2}-\frac{p-1}{n-p}\left(1-R^{2}\right)
$$

Being:

$\hat{y}$ - estimation of seedling emergence, in percentage; A - asymptotic value when the time, days after sowing, tends to infinity, that is, the maximum obtained in percentage; exp - exponential; DAS - days after sowing, time of evaluation; Xo - represents the time to obtain at least $70 \%$ of the asymptotic value, in days; B - constitutes an emergency start factor, with higher values indicating less time to start the process; $R_{a j}^{2}$ - adjusted coefficient of determination; $R^{2}$ - coefficient of determination, estimated through Pearson's correlation ( $r$ ), between observed 
and estimated values by the model, squared; $\mathrm{p}$ - number of parameters in the model; $\mathrm{n}$ number of observations.

Data were analyzed for normality using the Kolmogorov-Smirnov test ( $p \leq 0.05)$, being transformed into log $(y+10)$ when not adjusted to normal distribution. Then, analysis of variance was performed. The effects of polymer and electrical conductivity of water were fitted to polynomial regression using the F-test ( $p \leq 0.10$ ). The frequency of irrigation and the effects of container sizes were tested by orthogonal contrasts, using the F-test ( $p \leq$ 0.05). They were also submitted to principal component analysis (PCA) and cluster analysis based on the scores of treatments. The criterion used to classify the variable into components was based on the $0.5\left(\lambda^{-0.5}\right)$, where $\lambda$ is the eigenvalue of the component (Ovalles \& Collins, 1988). The parameters of the logistic model were interpreted as a function of the factors studied.

\section{Results and Discussion}

Emergence was estimated from $85.08 \%$ to $98.63 \%$ (parameter A), with at least $70 \%$ of the curve asymptotic obtained between 18 and 22 days after sowing (parameter Xo), coefficient of start of the emergence process (parameter B) from 2.42 to 3.29, initiating emergence between 13 and 16 days and ending between 23 and 26 days after sowing, and adjusted coefficients of determination - $R_{a j}^{2}$ between 0.9286 and 0.9651 in the evaluated treatments (Figure 1).

Among the variables studied, only the relationship between leaf indices of chlorophyll $a / b$, initial fluorescence, relationship between photochemical and nonphotochemical processes, leaf temperature, stomatal conductance, and transpiration did not have normal distribution (based on the Kolmogorov-Smirnov test, $p>0.05)$, being transformed into $\log (x+10)$.

Both for the leaf indexes of chlorophyll $a$, relationship between $a / b$, and total as for the maximum and variable fluorescence, as well as for leaf temperature, internal $\mathrm{CO}_{2}$ concentration, and the relationship between internal and environmental carbon, the effects of electrical conductivity of water and polymer were tested on the average of the two irrigation frequencies, while for the other variables the effects of quantitative factors were presented for the two irrigation frequencies as this factor was significant and/or the interaction with the Box's Central Composite was significant ( $p \leq 0.05)$. 

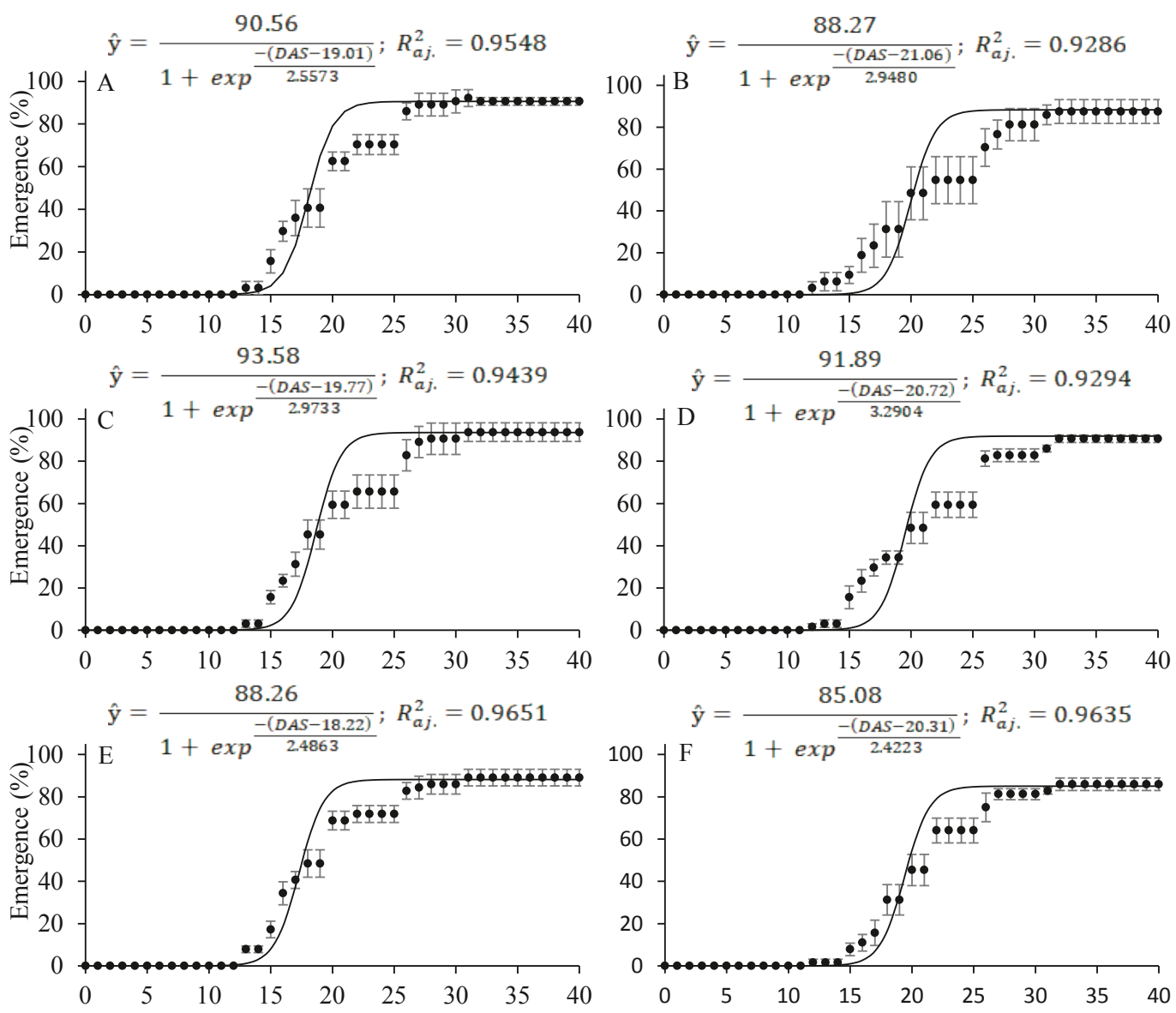
$\hat{\mathrm{y}}=\frac{98.63}{\underline{-(D A S-19.52)}} ; R_{a j .}^{2}=0.9439$

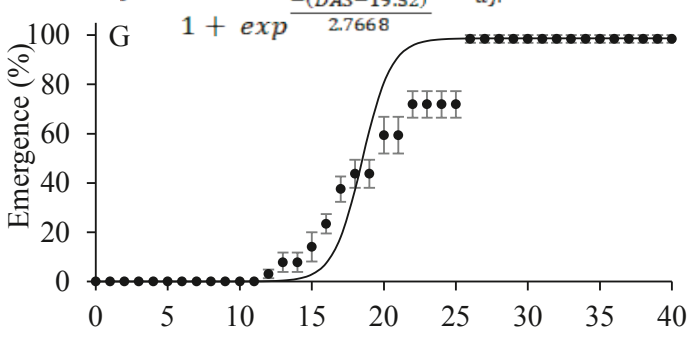
$\hat{\mathrm{y}}=\frac{94.28}{\frac{-(D A S-21.99)}{3.0210}} ; R_{a j .}^{2}=0.9489$

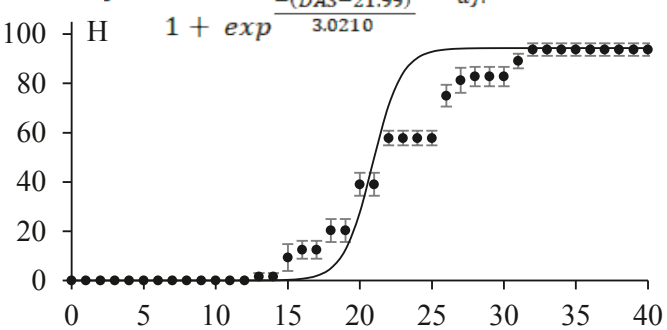
$\hat{\mathrm{y}}=\frac{90.37}{\underline{-(D A S-19.99)}} ; R_{a j .}^{2}=0.9516$

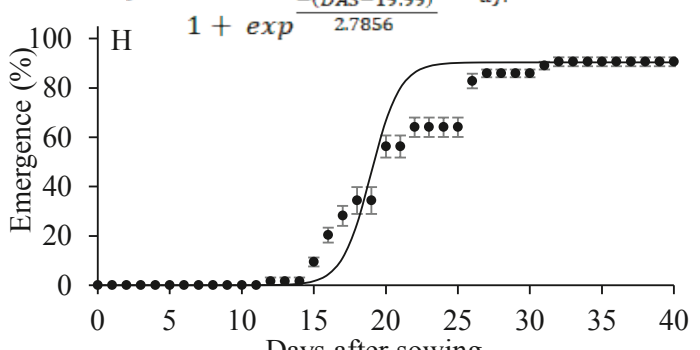
$\hat{\mathrm{y}}=\frac{89.48}{1+\exp \frac{-(D A S-20.66)}{29594}} ; R_{a j .}^{2}=0.9438$

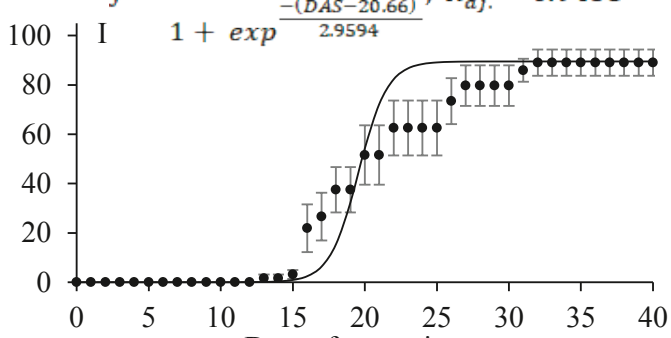

$\begin{array}{lllllllllll}\text { Treatment (Table 1) } & 1 & 2 & 3 & 4 & 5 & 6 & 7 & 8 & 9 & 10\end{array}$

Figure

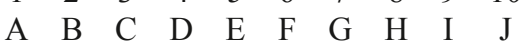

Figure 1. Emergence of Talisia esculenta seedlings as a function of the days after sowing (DAS) in each treatment. 


\section{Effects of irrigation frequency}

For the leaf indexes of chlorophyll $a$, ratio $a / b$ and total, initial, maximum, and variable chlorophyll a fluorescence, relationship between photochemical and non-photochemical processes, quantum efficiency of photosystem II, leaf temperature, internal carbon dioxide concentration, relationship between internal and environmental carbon, and water use efficiency in $T$. esculenta seedlings, there was no effect of irrigation frequency ( $p>0.05$ ).
While reducing the frequency of irrigation from daily to alternate days reduced the leaf index of chlorophyll 'b' of 12.45 from 11.79, - 5\% (Figure 2A), the stomatal conductance from 0.0247 to $0.0178 \mathrm{~mol} \mathrm{H}_{2} \mathrm{O} \mathrm{m}^{-2} \mathrm{~s}^{-1},-28 \%$ (Figure 2B), transpiration from 1.02 to 0.85 $\mathrm{mmol} \mathrm{H}_{2} \mathrm{O} \mathrm{m}^{-2} \mathrm{~s}^{-1}$, - 17\% (Figure 2C), the net assimilation of carbon dioxide from 2.52 to $1.95 \mu \mathrm{mol} \mathrm{CO} \mathrm{m}^{-2} \mathrm{~s}^{-1},-23 \%$ (Figure 2D), and the instantaneous carboxylation efficiency from 0.0125 to $0.0092 \mathrm{~mol} \mathrm{CO}_{2} \mathrm{~m}^{-2} \mathrm{~s}^{-1},-26 \%$ (Figure 2E), respectively.
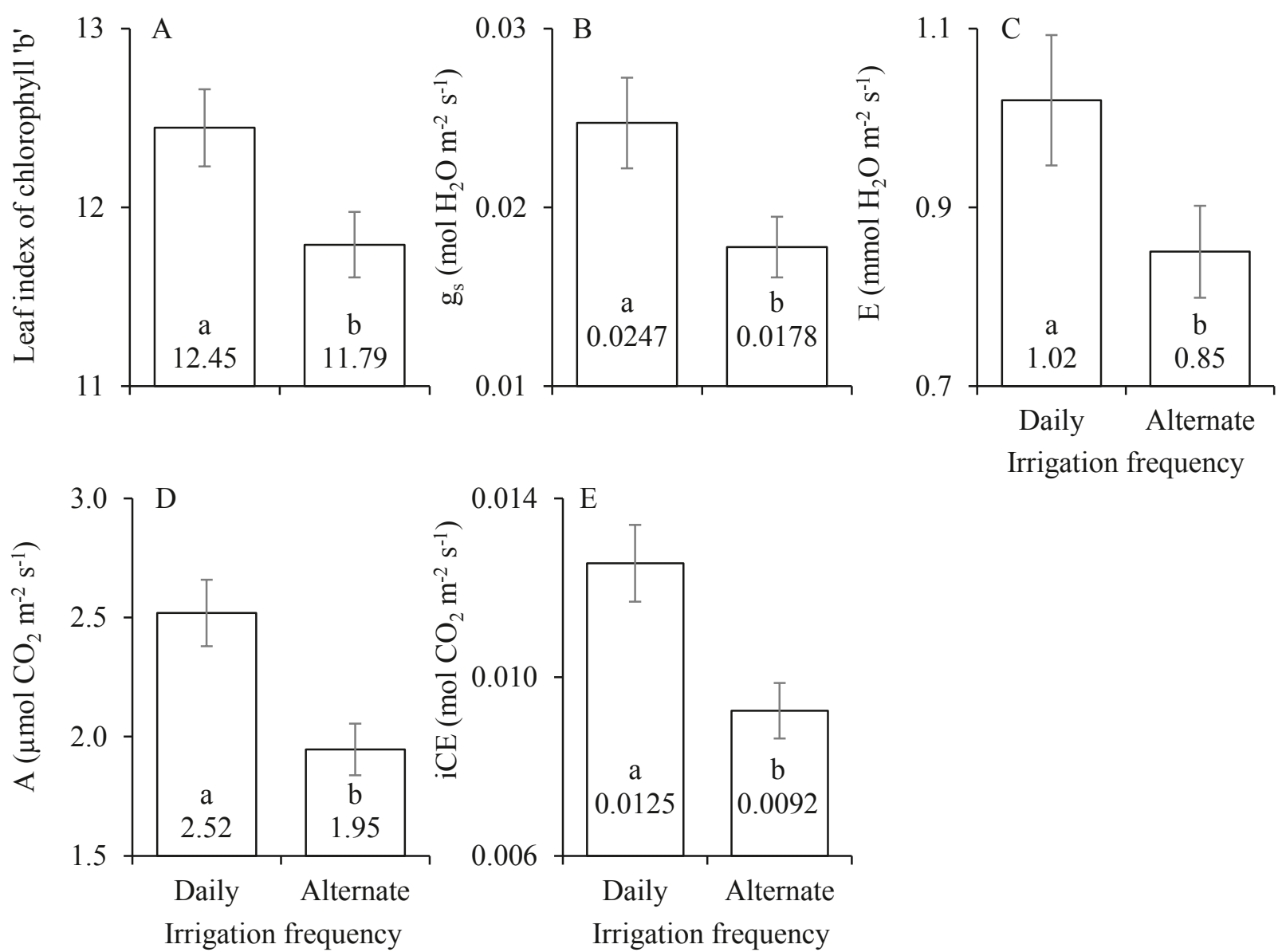

Figure 2. Mean values \pm standard error for the leaf index of chlorophyll $b(A)$, stomatal conductance - $\mathrm{g}_{\mathrm{s}}(\mathrm{B})$, transpiration - $\mathrm{E}(\mathrm{C})$, net $\mathrm{CO}_{2}$ assimilation - $\mathrm{A}(\mathrm{D})$, and instant carboxylation efficiency - iCE (E) in Talisia esculenta seedlings in relation to the frequency of irrigation. Means followed by the same letter do not differ by the $\mathrm{F}$ test $(\mathrm{p} \leq 0.05)$. 
Among the consequences of reducing the frequency of irrigation, we can mention the lower water content in the substrate (Felippe et al., 2019). This decrease, as observed in Jatropha curcas seedlings, provides a loss in leaf water potential, as it changes the concentrations of solutes such as carbohydrates, proteins, and amino acids in both roots and leaves (Moura, Nogueira, Silva, \& Lima, 2016), as well as reducing gas exchange in T. esculenta (Figure 1) and in Eucalyptus dunnii Maiden (Felippe et al., 2019), and consequently decreased the accumulation and allocation of biomass as recorded in $A$. squamosa (A. R. Silva et al., 2018a).

However, the loss in net assimilation of $\mathrm{CO}_{2}$ in $\mathrm{T}$. esculenta (Figure 2D) cannot be attributed only to lower stomatal conductance under lower irrigation frequency (Figure 2B), which have a Pearson correlation of 0.54 ( $t=$ 5.67; $p<0.0001)$. Since water stress increases stomatal resistance, reducing the passage of water vapor through the absorption of ions and the synthesis of osmotically active solutes (Taiz et al., 2017) and consequently reducing leaf transpiration (Figure 2C). Because, in addition to the relationship between internal and environmental carbon (relative stomatal limitation) having no effect on the frequency of irrigation (Table 2), it was in the limiting threshold according to Berry and Downton (1982) who defined the interval between 0.6 and 0.8 as suitable for $\mathrm{C} 3$ plants.

The reduction in carbon dioxide assimilation under increased irrigation frequency is associated with lower instantaneous carboxylation efficiency (Figures 2 and 7), with a Pearson correlation of 0.91 ( $t=19.89 ; p<0.0001)$. Probably having occurred due to negative changes in biochemical reactions that occur in the chloroplast stroma due to water stress. Because, there was no effect of the irrigation depth on photochemical processes, with quantum efficiency of photosystem II in $T$. esculenta seedlings of, on average, 0.83 electrons quantum ${ }^{-1}$, being in the range of 0.80-0.86 considered for plants without stress (Roháček, 2002). For the relationship between photochemical and non-photochemical processes (Fv/Fo), the appropriate is between 4 and 6 (Roháček, 2002), however, an average of 6.5 was obtained, probably indicating greater energy use in photochemical reactions.

\section{Effects of water salinity and polymer}

The increase in the electrical conductivity of the irrigation water harmed the emergence of seedlings. The maximum percentage of emergence $(98.7 \%)$ was reduced to an electrical conductivity of 2.9 $\mathrm{dS} \mathrm{m}^{-1}$, reducing to $87.4 \%$ (Figure $3 \mathrm{~A}$ ). With losses not only in emergence, but both in time to reach maximum emergence (Figure 3C) and in emergence speed (Figure 3E). The time to reach the maximum emergence went from 19 to 21 days, an increase of $17 \%$, while the emergence speed index reduced from 0.41 to $0.35(-15 \%)$ under the respective conductivities of 0.3 and $5.0 \mathrm{dS} \mathrm{m}^{-1}$. The polymer, on the other hand, only had an effect on the percentage of emergence with an increase from $87.0 \%$ to $94.5 \%$ under doses of 0 and $0.6 \mathrm{~g} \mathrm{dm}^{-3}$, respectively, but with a reduction to $86.3 \%$ in the dose of $1.2 \mathrm{~g} \mathrm{dm}^{-3}$ (Figure 3B).

The increase in the concentration of salts reduces the water potential (Taiz et al., 2017), making it difficult for seeds, seedlings, 
and plants to absorb water. This effect causes delay and reduction of seedling emergence under saline conditions (Bezerra et al., 2014; Sá et al., 2015; F. S. Oliveira et al., 2016) as observed in T. esculenta (Figure 3), in addition to promoting lower growth of seedlings of this species (Melo et al., 2017) and of
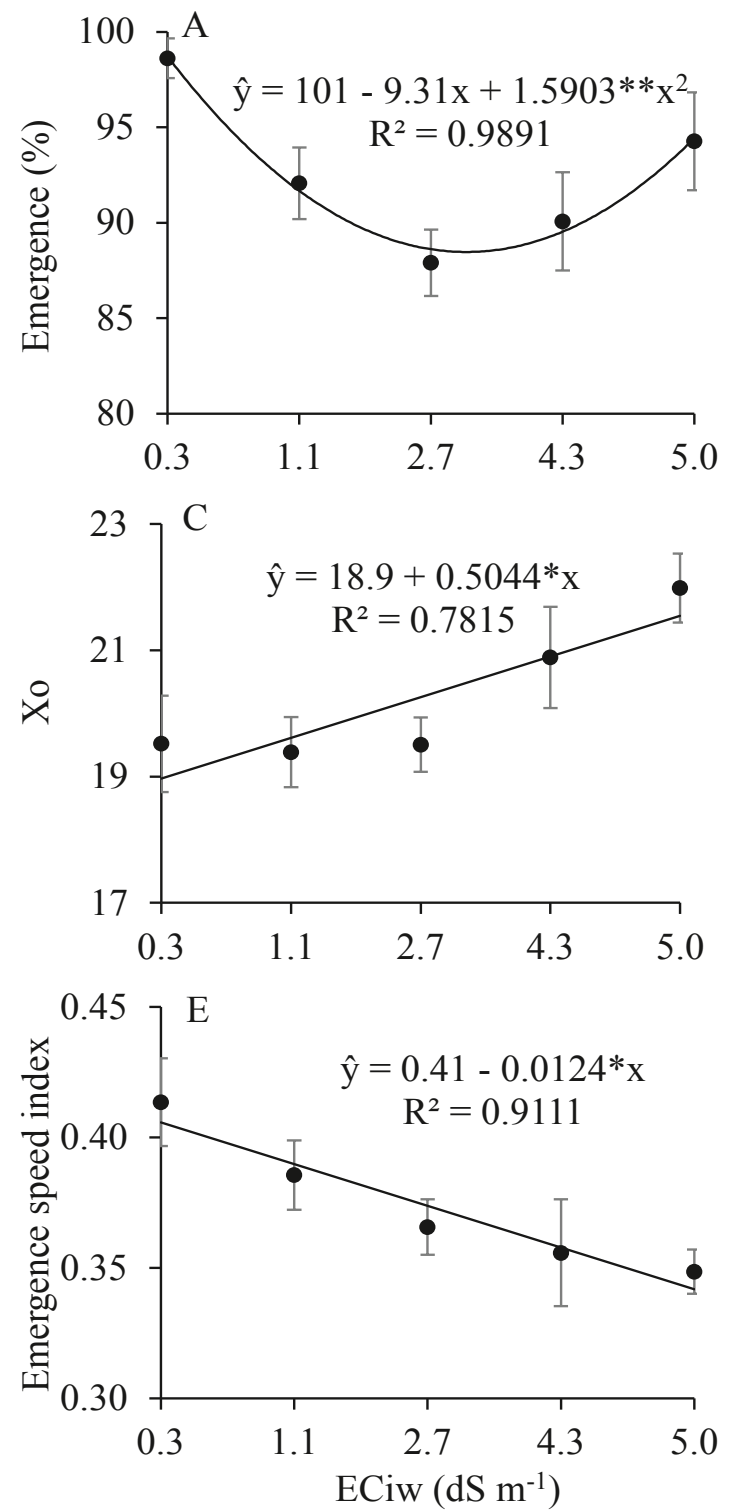

other species such as, for example, $P$. edulis (Bezerra et al., 2014, 2019), A. squamosa (A. R. Silva et al., 2018a,b), A. heterophyllus (Oliveira et al., 2017), Pistacia vera L. (Rahneshan et al., 2018), Carica papaya L. (E. C. Nascimento et al., 2020), Solanum lycopersicum L. (Shin et al., 2020).
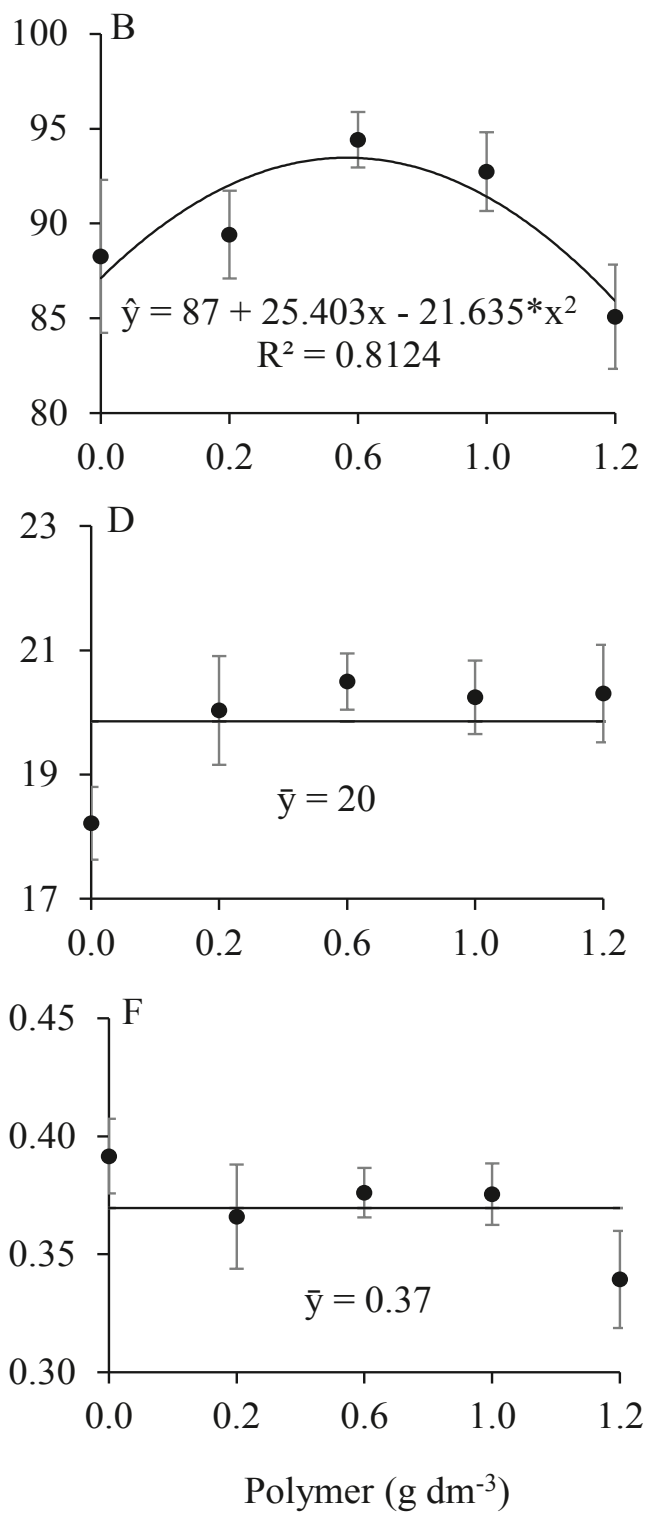

Figure 3. Percentage of emergence (model parameter A), period for maximum emergence (model parameter $\mathrm{Xo}$ ), and emergence speed index of Talisia esculenta seedlings as a function of the electrical conductivity of irrigation water - ECiw $(A, C, E)$ and polymer doses $(B, D, F) .{ }^{*}$ and ${ }^{* *}$ : significant at $5 \%$ and $1 \%$ probability by the $F$ test, respectively. 
The leaf index of chlorophyll a in $T$. esculenta seedlings was not affected by the linear interaction between electrical conductivity of water and polymer, and there was no adjustment for salinity $(F \leq 1.43 ; p>$ $0.10)$. However, increasing the polymer from 0.00 to $0.60 \mathrm{~g} \mathrm{dm}^{-3}$ provided a reduction in this index from 27.3 to 26.0, respectively, recovering the value under the dose of $1.20 \mathrm{~g}$ $\mathrm{dm}^{-3}$ (Figure 4A). For the chlorophyll leaf $b$, under daily irrigation frequency, there was no interaction of regression of these quantitative factors and adjustment to polymer doses $(\mathrm{F} \leq$
1.19; $p>0.10)$. However, the unitary increase in electrical conductivity reduced this index by 0.27 (Figure 4B). With the frequency on alternate days, there was no adjustment to the regression to quantitative factors, both isolated and in interaction ( $F \leq 2.47 ; p>0.10$ ). For the relationship $a / b$ and the total contents of leaf chlorophyll, there was no interaction of regression of these quantitative factors and adjustment to models as a function of electrical conductivity of irrigation water and polymer doses $(F \leq 2.74 ; p>0.10)$.
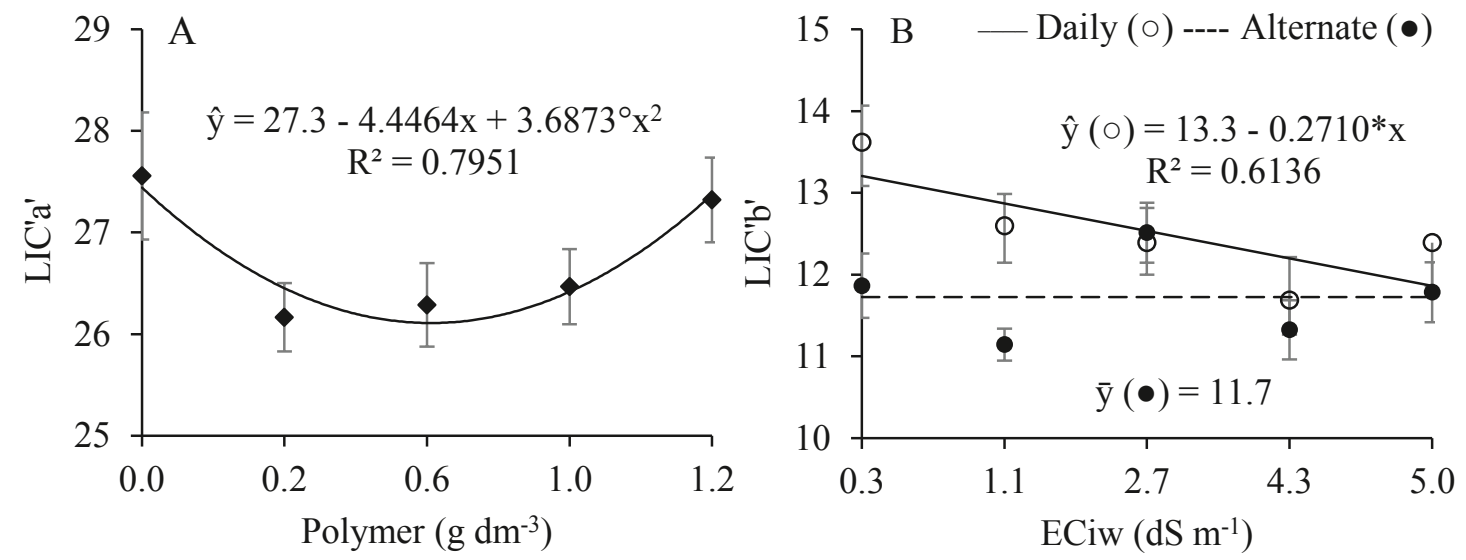

Figure 4. Leaf indexes of chlorophyll a in Talisia esculenta seedlings as a function of the doses of polymer (A) and chlorophyll $b$, under daily $(\circ)$ and alternate $(\bullet)$ irrigation frequencies, as a function of electrical conductivity of irrigation water - ECiw (B). ${ }^{\circ}$ and *: significant at $10 \%$ and $5 \%$ probability by the F test, respectively.

The initial fluorescence of chlorophyll a in $T$. esculenta seedlings, under daily irrigation frequency, had no adjustment for quantitative factors, salinity, and polymer, alone or in interaction ( $\mathrm{F} \leq 2.45 ; \mathrm{p}>0.10$ ). However, the interaction of the regression between electrical conductivity of irrigation water and polymer for irrigation on alternate days was significant $(F=4.92 ; p=0.03)$ but with a low coefficient of determination $\left(R^{2}=\right.$
0.4431). For maximum fluorescence, both the interaction with irrigation frequency and the adjustments to quantitative factors were not significant $(F \leq 2.76 ; p>0.10$ ), while for variable fluorescence the interaction was significant ( $F$ = 4.13; $p=0.04$ ) but with a low coefficient of determination $\left(R^{2}=0.3867\right)$.

In the relationship between photochemical and non-photochemical processes (Fv/Fo) in $T$. esculenta seedlings, 
under daily irrigation frequency, there was no functional regression model as a function of electrical conductivity of irrigation water and polymer alone or in interaction $(F \leq 2.26 ; p>$ $0.10)$. However, under alternating frequency, there was an interaction of these quantitative factors $(F=2.95 ; p=0.09)$. The increase in conductivity reduced the $\mathrm{Fv} / \mathrm{Fo}$, while the increase in polymer increased this variable under electrical conductivity lower than 2.9 dS $\mathrm{m}^{-1}$ and reduced it under higher salinity, the maximum being 13.2 obtained in the combination of $0.3 \mathrm{dS} \mathrm{m}^{-1}$ associated with $1.20 \mathrm{~g} \mathrm{dm}^{-3}$ of polymer and the lowest average of 3.85 in the combination between $2.9 \mathrm{dS} \mathrm{m}^{-1}$ and $0.42 \mathrm{~g} \mathrm{dm}^{-3}$ of polymer (Figure $5 \mathrm{~A}$ ).

The quantum efficiency of photosystem ॥ (Fv/Fm) in $T$. esculenta seedlings reduced at each unitary increase in the electrical conductivity of the irrigation water by $0.0212(2 \%)$, when irrigated daily
(Figure 5B). While for the polymer there was no adjustment to the regression alone and in interaction with salinity $(F \leq 1.22 ; p>0.10)$. Under the alternating frequency of irrigation, the regression of these quantitative factors was significant $(F=8.57 ; p=0.00)$, but the coefficient of determination was only 0.3910 .

The stomatal conductance to water vapor in $T$. esculenta seedlings, under daily irrigation, reduced to the electrical conductivity of the irrigation water of $4.1 \mathrm{dS}$ $\mathrm{m}^{-1}$ where it obtained $0.0152 \mathrm{~mol} \mathrm{H}_{2} \mathrm{O} \mathrm{m}^{-2} \mathrm{~s}^{-1}$, $58 \%$ reduction compared to conductivity of $0.3 \mathrm{dS} \mathrm{m}^{-1}$ (Figure 6A). No functional model was observed for the polymer $(F \leq 0.95 ; p>0.10)$. With the alternating frequency of irrigation, the regression of these quantitative factors was significant $(F=4.56 ; p=0.04)$, however it had a low coefficient of determination $\left(R^{2}=\right.$ 0.3025).
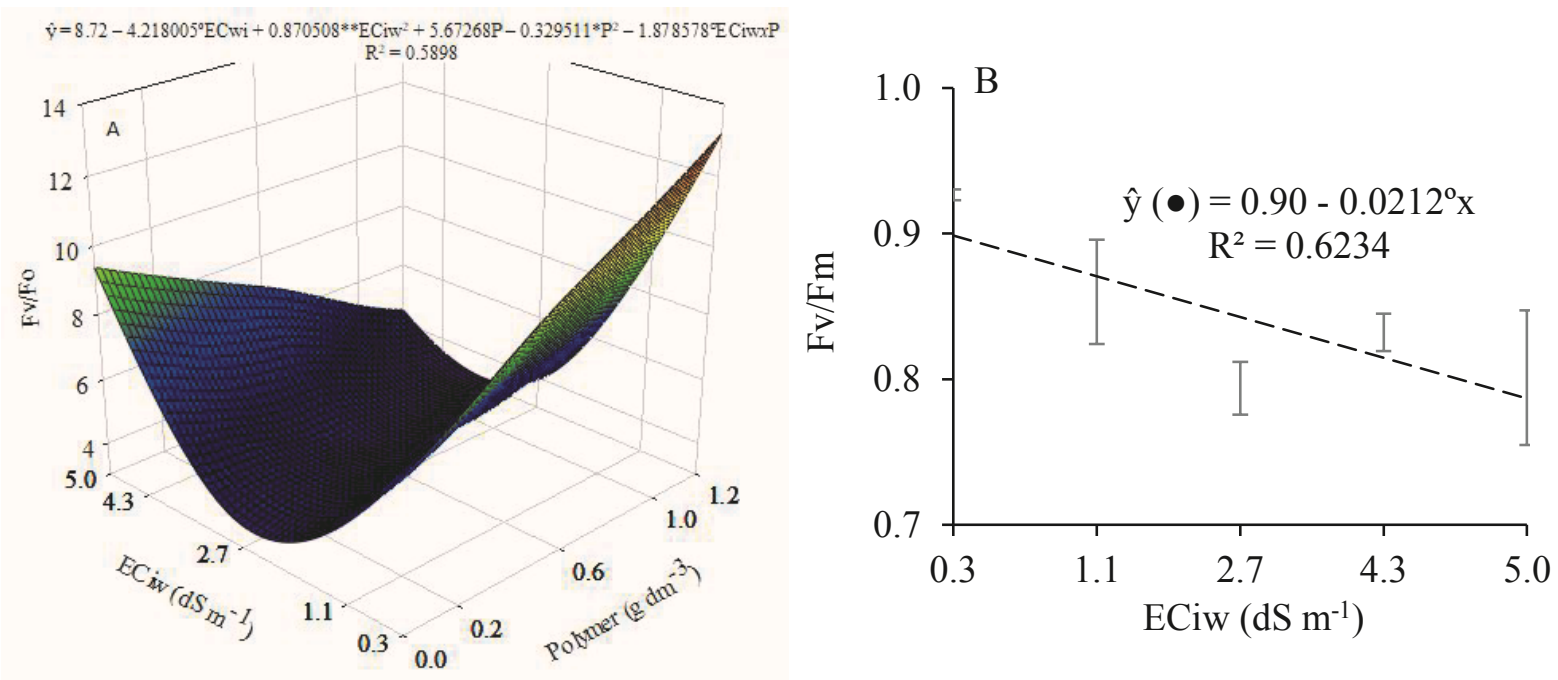

Figure 5. Relationship between photochemical and non-photochemical (Fv/Fo) processes in Talisia esculenta seedlings, under alternating irrigation frequency, as a function of the electrical conductivity of irrigation water - ECiw and the polymer doses (A) and, quantum efficiency of photosystem II (Fv/Fm), under alternating irrigation frequency, as a function of the electrical conductivity of irrigation water (B). ${ }^{\circ},{ }^{*}$, and **: significant at $10 \%, 5 \%$, and $1 \%$ probability by the $\mathrm{F}$ test, respectively. 
For leaf temperature $(F \leq 2.72 ; p>$ 0.10), internal $\mathrm{CO}_{2}$ concentration $(\mathrm{F} \leq 1.83$; $p$ $>0.10)$, and the relationship between internal and environmental carbon data $(F \leq 1.71$; $p$ $>0.10$ ) in the seedlings of $T$. esculenta, the regressions did not adjust as a function of the electrical conductivity of the irrigation water and the polymer. While transpiration had an interaction effect on the regression of these quantitative factors, both under daily irrigation and on alternate days ( $F \leq 12.58 ; p=0.00$ ), however, the models had a low coefficient of determination $\left(R^{2}<0.50\right)$.

The net assimilation of $\mathrm{CO}_{2}$ in $T$. esculenta seedlings reduced by 0.32 (10\%) and 0.17 (8\%) $\mu \mathrm{mol} \mathrm{CO}_{2} \mathrm{~m}^{-2} \mathrm{~s}^{-1}$ at each increase of $1 \mathrm{dS} \mathrm{m}^{-1}$ of the electrical conductivity of the water irrigation, when irrigated at daily frequencies and on alternate days, respectively (Figure $6 \mathrm{C}$ ), with the gain obtained in daily irrigation in relation to alternate days (Figure 1D) reduced in higher salinities. As for the polymer, every $1 \mathrm{~g} \mathrm{dm}^{-3}$ net photosynthesis was reduced by $0.77 \mathrm{CO}_{2}$ $\mathrm{m}^{-2} \mathrm{~s}^{-1}$ for the daily frequency (Figure 6D) and in the alternate days, even with adjustment to linear regression ( $F=3.62 ; p=0.06)$, the model had a low coefficient of determination $\left(R^{2}=0.0262\right)$.

The efficiency of water use in $T$. esculenta seedlings irrigated daily increased the electrical conductivity of the irrigation water from 0.3 to $2.5 \mathrm{dS} \mathrm{m}^{-1}$, increasing from 2.33 to $2.98 \mu \mathrm{mol} \mathrm{CO} \mathrm{mmol}^{-1} \mathrm{H}_{2} \mathrm{O}$, a gain of $28 \%$, reducing to 2.19 under the highest salinity (Figure 6E). While the increase in polymer doses reduced it by $0.77 \mu \mathrm{mol} \mathrm{CO}_{2}$ $\mathrm{mmol}^{-1} \mathrm{H}_{2} \mathrm{O}$ (Figure 6F). Under the frequency of alternate days, no functional model of this efficiency was obtained as a function of salinity and polymer ( $\mathrm{F} \leq 0.77 ; p>0.10)$.

The instantaneous efficiency of carboxylation reduced with the unitary increase in the electrical conductivity of the irrigation water at the rates of 1.5 and 0.8 $\mathrm{mmol} \mathrm{CO}_{2} \mathrm{~m}^{-2} \mathrm{~s}^{-1}$, when irrigating daily and on alternate days, respectively (Figure 6G). That is, the reduction under daily irrigation was from 0.0160 to $0.0089 \mathrm{~mol} \mathrm{CO}_{2} \mathrm{~m}^{-2} \mathrm{~s}^{-1}$ $(-44 \%)$ and irrigating on alternating days from 0.0109 to $0.0071 \mathrm{~mol} \mathrm{CO}_{2} \mathrm{~m}^{-2} \mathrm{~s}^{-1}(-35 \%)$, under the respective conductivities of 0.3 and $5.0 \mathrm{dS} \mathrm{m}^{-1}$. The incorporation of polymer in the substrate also reduced this efficiency when irrigating daily with $3.6 \mathrm{mmol} \mathrm{CO}_{2} \mathrm{~m}^{-2}$ $\mathrm{s}^{-1}$ per unit increase of the input, falling from 0.0144 to $0.0101 \mathrm{~mol} \mathrm{CO}_{2} \mathrm{~m}^{-2} \mathrm{~s}^{-1}(-30 \%)$ under the conditions without and with $1.2 \mathrm{~g} \mathrm{dm}^{-3}$, respectively (Figure $6 \mathrm{H}$ ). Irrigating on alternate days, a model was adjusted $(F=3.66 p=0.06)$, however with low efficiency in the explanation $\left(R^{2}=0.0464\right)$.

Four main components, representing $82.3 \%$ of the total variance, were retained in the analysis. It was observed that in component one, with $25.7 \%$ of the variance and eigenvalue $(\lambda)$ of 4.37 , the variables related to photochemistry were retained with the following contributions of $19.4 \%$ of Fv/Fm, $19.0 \%$ of $\mathrm{Fo}, 15.0 \%$ of $\mathrm{Fv} / \mathrm{Fo}, 9.3 \%$ of $\mathrm{gs}$, and $7.7 \%$ of Fv with the respective eigenvectors of $0.4400,-0.4353,0.3878,0.3045$, and 0.2783 . The higher photochemical efficiency (Fv/Fm) is associated with the reduction in the energy absorbed by the antenna-complex and not transmitted (Fv/Fo), initial fluorescence (Fo), as well as the highest stomatal conductance - $\mathrm{g}_{\mathrm{s}}$ (Figure 7). 

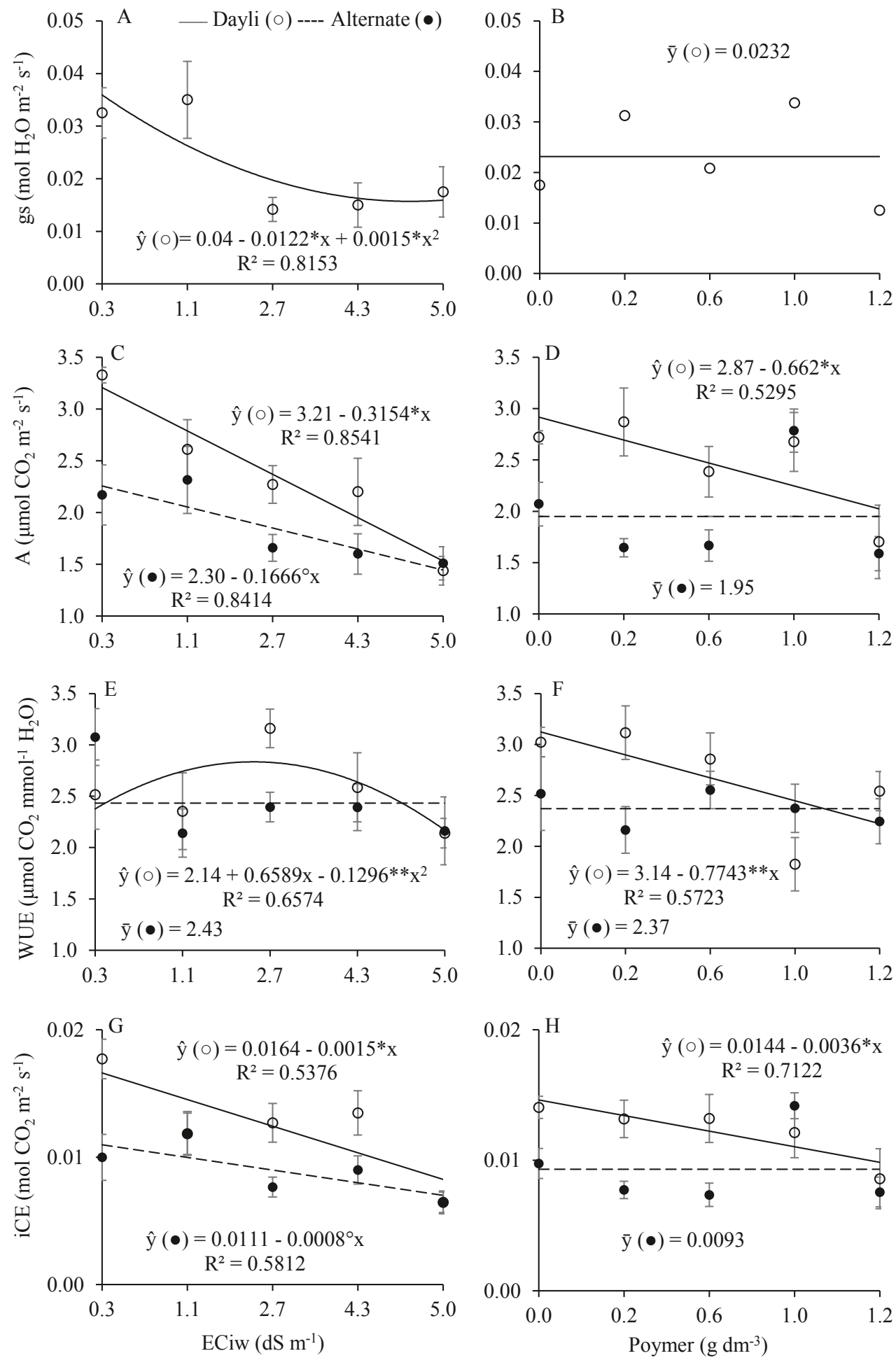

Figure 6. Stomatal conductance to water vapor $-\mathrm{g}_{\mathrm{s}^{\prime}}$ net $\mathrm{CO}_{2}$ assimilation - $\mathrm{A}$, water use efficiency - WUE, and instant carboxylation efficiency - iCE in Talisia esculenta seedlings, under daily (o) and/ or alternating irrigation $(\bullet)$ frequencies, depending on the electrical conductivity of the irrigation water - ECiw $(A, C, E, G)$ and the polymer doses $(B, D, F, H) .{ }^{\circ},{ }^{*}$, and ${ }^{* *}$ : significant at $10 \%, 5 \%$, and $1 \%$ probability by the $\mathrm{F}$ test, respectively. 

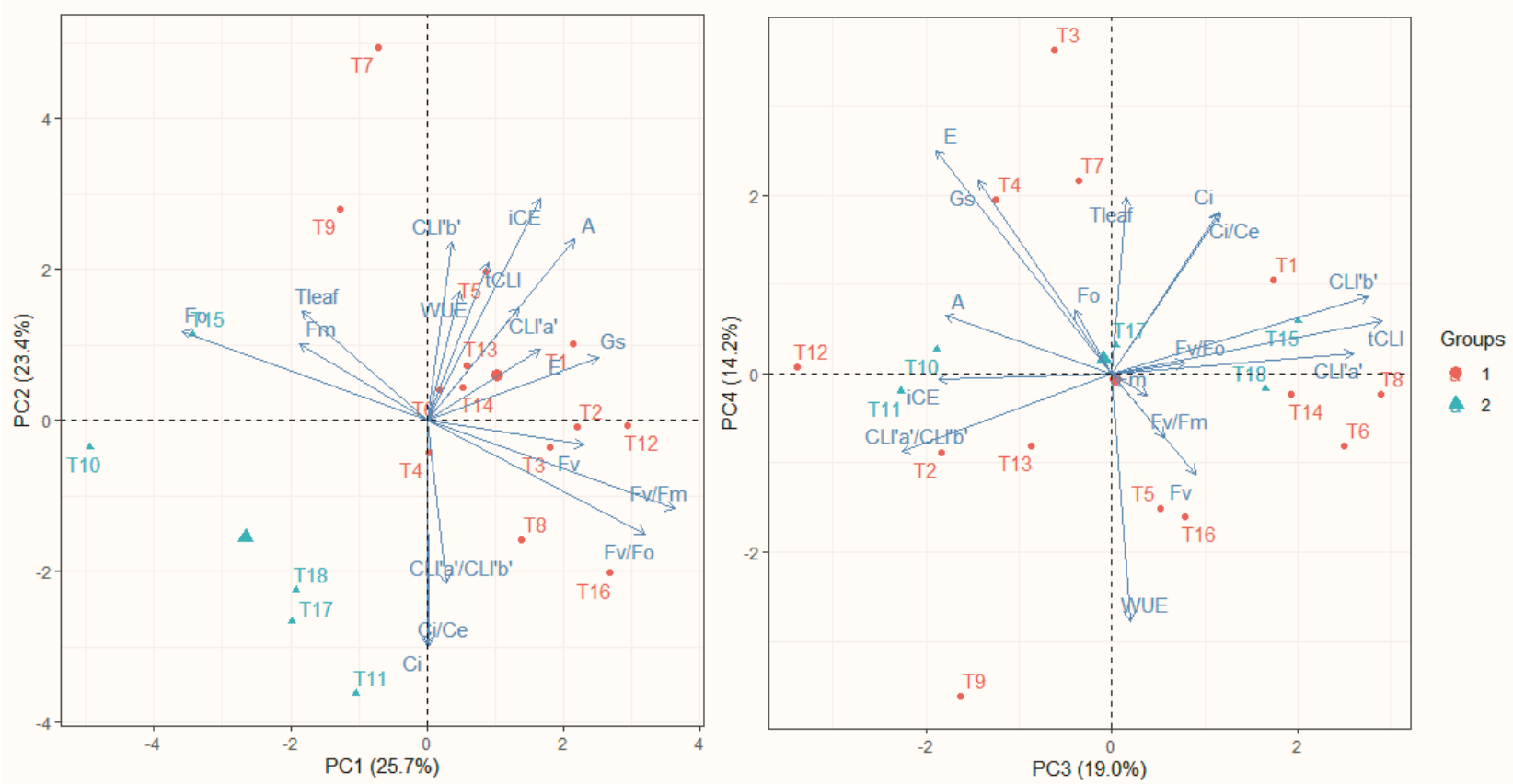

Figure 7. Dispersion of physiological variables in Talisia esculenta seedlings and treatment groupings (Table 1) based on the scores of the first and the second (A), and of the third and the fourth (B) principal component.

In the second component (23.4\% of the variance and eigenvalue of 3.98), the relationship between chlorophyll and gas exchange was observed, that is, light absorption and photosynthesis. The leaf internal concentration of carbon dioxide had the greatest contribution (14.5\%) in this group, followed by the relationship between internal and environmental carbon (14.4\%), instantaneous carboxylation efficiency (14.0\%), net assimilation of $\mathrm{CO}_{2}(9.3 \%)$, and leaf indexes of chlorophyll 'b' (9.0\%), ratio between 'a'/'b' (7.5\%), and total (7.1\%) with eigenvectors of $-0.3808,-0.3797,0.3737,0.3053,0.3002$, -0.2743 , and 0.2661 , respectively. Where the highest leaf consumption of carbon dioxide was caused by the reduction in the relative stomatal limitation, associated with the improvement in the intrinsic efficiency of carboxylation and, consequently, greater net assimilation of $\mathrm{CO}_{2}$ (Figure 7). Also, the greater synthesis of chlorophyll $b$, a photoprotective pigment, was observed.

For the third component, with $19.0 \%$ of the total variance and eigenvalue of 3.23 , the relationship between leaf chlorophyll contents was observed. The major contribution was made by total chlorophyll (18.7\%), followed by leaf indexes of chlorophyll $b$ (16.9\%), a (15.0\%), ratio $a / b(11.3 \%)$, and transpiration (7.9\%) with eigenvectors of $0.4324,0.4110$, $0.3878,-0.3365$, and -0.2819 .

While the fourth component (14.2\% of the variance) represents water relations, with the following contributions of $22.8 \%$ in water use efficiency and eigenvector of -0.4770 , $18.6 \%$ in transpiration with eigenvector of $0.4331,13.9 \%$ in stomatal conductance with eigenvector of 0.3723 , and $11.6 \%$ in leaf 
temperature with eigenvector of 0.3406 , wherein the increase in water use efficiency is related to the reduction in transpiration, leaf conductance, and temperature (Figure 7).

In the cluster analysis, the treatments formed groups with group one representing mostly daily irrigation, and two, equivalent to irrigating on alternate days (Figure 7). In group one, the trend was observed that provides the best conditions for chlorophyll, fluorescence, and gas exchange in $T$. esculenta seedlings. That is, under likely more favorable water conditions there is greater synthesis of chlorophyll, greater quantum efficiency of the photosystem, and net assimilation of carbon dioxide.

Inaddition to the osmotic effect, excess salts can exert specific toxic action of soluble ions (Taiz et al., 2017) altering physiological processes such as, for example, reducing the concentration of photosynthetic pigments, changing chlorophyll a fluorescence and photosystem efficiency being the most intense effect of prolonging the period under stress (Rahneshan et al., 2018; Zhao et al., 2019; Shin et al., 2020). The reduction in pigment synthesis, under conditions of salt stress, may be related to damage to metabolic pathways of synthesis and/or the strategy to save energy and carbon for the synthesis of compounds that help in stress mitigation. In this sense, an increase in the proline concentration in the leaves was observed (Shin et al., 2020) and in the roots, with changes in saccharide and polysaccharide contractions (Rahneshan et al., 2018) and in the antioxidant system (Zhao et al., 2019), with association between chlorophyll trends and carboxylation efficiency, and consequently for the net assimilation of $\mathrm{CO}_{2}$ (Figure 7). In Hymenaea courbaril, H. H. C. Nascimento et al. (2015) recommend that the classification of the tolerance of seedlings to salinity be carried out based on gas exchange and organic and inorganic solutes.

Regarding the polymer in the substrate, Fagundes et al. (2014) also observed that this input provided greater seed emergence, but only in Rangpur lime (Citrus limonia Osbeck). The polymer interferes with gas exchange in young plants, as observed in E. dunni (Felippe et al., 2019). These authors observed greater net assimilation of carbon dioxide in plants when the polymer was not used, and the main factor that reduced photosynthesis was water deficit, as also observed in Quillaja saponária Mol., where water stress reduced gas exchange (Espinoza, Santelices, Cabrera, \& Magni, 2017).

\section{Effects of container volume}

The effects of container volumes, for the daily and alternate frequency of irrigation, were not significant for parameters $A, B$, and $X o$ of the emergence logistic model and for the seedling emergence speed index for the leaf chlorophyll a, chlorophyll a fluorescence, leaf temperature, stomatal conductance, transpiration, net $\mathrm{CO}_{2}$ assimilation, and water use efficiency (Table 2). While under daily irrigation frequency, the reduction in container volume from 1.30 to $0.75 \mathrm{dm}^{3}$ provided a gain of $55 \mu \mathrm{mol} \mathrm{CO} \mathrm{mol}^{-1}$ air (33\%) in the internal concentration of carbon dioxide, from 0.14 (33\%) in the $c_{i} / c_{e}$ ratio and loss of 0.0054 mol $\mathrm{CO}_{2} \mathrm{~m}^{-2} \mathrm{~s}^{-1}(-35 \%)$ in the instantaneous efficiency of carboxylation which in the larger volume container were $166 \mathrm{\mu mol} \mathrm{CO}_{2} \mathrm{~mol}^{-1}$ air, 0.43 and $0.0155 \mathrm{~mol} \mathrm{CO}_{2} \mathrm{~m}^{-2} \mathrm{~s}^{-1}$, respectively. In the alternating frequency of irrigation, the reduction in container volume provided gains 
of $0.46(21 \%)$ in the $a / b$ ratio, of $5.53(26 \%)$ in the ratio between photochemical and nonphotochemical processes, of 0.10 (14\%) in the quantum efficiency of photosystem II, and reductions of 2.59 (21\%) and 3.91 (10\%) in leaf indices of 'b' and total chlorophyll, respectively, and 70 (64\%) and 125 (33\%) in the respective initial and maximum chlorophyll a fluorescence which in the $1.30 \mathrm{dm}^{3}$ container were $2.18,4.38,0.80,12.13,38.36,109$, and 542 , respectively.

\section{Table 2}

Mean values \pm standard error of the parameters of the emergence logistic model $\left(A, B\right.$, and $\left.X_{0}\right)$ and of the seedling emergence speed index (ESI), of the leaf indexes of chlorophyll $a$ (LIC'a'), $b$ (LIC'b'), $a / b$, and total (tLIC), initial (Fo), maximum (Fm), and variable (Fv) chlorophyll $a$, relationship between photochemical and non-photochemical processes (Fv/Fo), quantum efficiency of photosystem II (Fv/ $\mathbf{F m})$, leaf temperature (Tleaf), stomatal conductance $\left(\mathbf{g}_{\mathrm{s}}\right)$, internal concentration of carbon dioxide $\left(\mathbf{c}_{i}\right)$, relationship between internal carbon and environmental $\left(c_{i} / c_{e}\right)$, transpiration $(E)$, net $\mathrm{CO}_{2}$ assimilation (A), water use efficiency (WUE), and instant carboxylation efficiency (iCE) of Talisia esculenta seedlings in relation to the container volume (CtV) under daily and alternating irrigation frequencies

\begin{tabular}{lcccccc} 
& \multicolumn{5}{c}{ Daily irrigation } & \multicolumn{3}{c}{ Alternate day irrigation } \\
\cline { 2 - 7 } & $1.30 \mathrm{dm}^{3}$ & $0.75 \mathrm{dm}^{3}$ & CE & $1.30 \mathrm{dm}^{3}$ & $0.75 \mathrm{dm}^{3}$ & CE \\
\hline A & $90.37 \pm 2.12$ & $89.48 \pm 5.25$ & $-0.89^{\text {ns }}$ & - & - & - \\
B & $2.79 \pm 0.31$ & $2.96 \pm 0.63$ & $0.17^{\text {ns }}$ & - & - & - \\
Xo & $19.99 \pm 0.48$ & $20.66 \pm 1.16$ & $0.66^{\text {ns }}$ & - & - & - \\
\hline ESI & $0.37 \pm 0.01$ & $0.35 \pm 0.03$ & $-0.01^{\text {ns }}$ & - & - & - \\
LIC'a' & $26.09 \pm 1.09$ & $26.19 \pm 1.07$ & $0.10^{\text {ns }}$ & $26.24 \pm 0.86$ & $24.93 \pm 2.37$ & $-1.31^{\text {ns }}$ \\
LIC'b' & $11.76 \pm 0.72$ & $10.97 \pm 0.33$ & $-0.80^{\text {ns }}$ & $12.13 \pm 0.77$ & $9.53 \pm 1.02$ & $-2.59^{* *}$ \\
'a'/'b' & $2.23 \pm 0.04$ & $2.39 \pm 0.09$ & $0.16^{\text {ns }}$ & $2.18 \pm 0.07$ & $2.64 \pm 0.18$ & $0.46^{* *}$ \\
tLCl & $37.85 \pm 1.82$ & $37.16 \pm 1.24$ & $-0.70^{\text {ns }}$ & $38.36 \pm 1.63$ & $34.46 \pm 3.19$ & $-3.91^{*}$ \\
Fo & $109 \pm 9$ & $98 \pm 30$ & $-11^{\text {ns }}$ & $109 \pm 19$ & $39 \pm 3$ & $-70^{* *}$ \\
Fm & $529 \pm 27$ & $485 \pm 21$ & $-44^{\text {ns }}$ & $542 \pm 39$ & $417 \pm 10$ & $-125^{* *}$ \\
Fv & $420 \pm 23$ & $387 \pm 15$ & $-33^{\text {ns }}$ & $433 \pm 22$ & $378 \pm 7$ & $-55^{\text {ns }}$ \\
Fv/Fo & $3.93 \pm 0.36$ & $5.81 \pm 2.19$ & $1.88^{\text {ns }}$ & $4.38 \pm 0.76$ & $9.91 \pm 0.79$ & $5.53^{*}$ \\
Fv/Fm & $0.79 \pm 0.01$ & $0.80 \pm 0.05$ & $0.01^{\text {ns }}$ & $0.80 \pm 0.02$ & $0.91 \pm 0.01$ & $0.10^{*}$ \\
\hline Tleaf & $37.13 \pm 0.72$ & $36.38 \pm 1.22$ & $-0.75^{\text {ns }}$ & $36.55 \pm 1.31$ & $35.93 \pm 0.68$ & $-0.62^{\text {ns }}$ \\
gs & $0.0125 \pm .0025$ & $0.0150 \pm 0.0029$ & $0.0025^{\text {ns }}$ & $0.0150 \pm 0.00029$ & $0.0125 \pm 0.0025$ & $-0.0025^{\text {ns }}$ \\
ci & $166 \pm 21$ & $221 \pm 20$ & $55^{*}$ & $246 \pm 25$ & $268 \pm 13$ & $22^{\text {ss }}$ \\
ci/ce & $0.43 \pm 0.05$ & $0.57 \pm 0.05$ & $0.14^{*}$ & $0.63 \pm 0.07$ & $0.69 \pm 0.04$ & $0.06^{\text {ns }}$ \\
E & $0.61 \pm 0.06$ & $0.66 \pm 0.10$ & $0.05^{\text {ns }}$ & $0.54 \pm 0.01$ & $0.32 \pm 0.02$ & $-0.23^{\text {ns }}$ \\
A & $2.39 \pm 0.23$ & $2.13 \pm 0.27$ & $-0.26^{\text {ns }}$ & $1.32 \pm 0.12$ & $0.68 \pm 0.11$ & $-0.64^{\text {ns }}$ \\
WUE & $3.92 \pm 0.04$ & $3.45 \pm 0.64$ & $-0.47^{\text {ns }}$ & $2.42 \pm 0.19$ & $2.22 \pm 0.47$ & $-0.20^{\text {ns }}$ \\
iCE & $0.0155 \pm 0.0033$ & $0.0101 \pm 0.0022$ & $-0.0054^{*}$ & $0.0056 \pm 0.0011$ & $0.0025 \pm 0.0004$ & $-0.0031^{\text {ns }}$
\end{tabular}

CE - Contracts estimate between container volumes of 1.30 and $0.75 \mathrm{dm}^{3} ;{ }^{n},{ }^{*}$, and **: not significant and significant at $5 \%$ and $1 \%$ probability by the $\mathrm{F}$ test, respectively. 
The main factors that affect seed germination and consequently the emergence of $T$. esculenta seedlings are the fermentation period for pulp removal, the drying period, and temperature (Alves, Silva, Gonçalves, Cardoso, \& Alves, 2009; Cardoso, Alves, \& Alves, 2015). The difference in the volume of the container for the production of seedlings did not affect the emergence of Hancornia speciosa Gomes (A. B. V. Silva, Costa, Pinho, \& Reis, 2020) and Lagenaria siceraria (Mol.) Standl (Santos, Chiomento, Bortoluzzi, \& Petry, 2021). Adequate supply of water for the seeds, without dormancy, associated with temperature and light are the main factors in the germination process (Taiz et al., 2017). However, the reduction in container volume can promote changes in seedling physiology (Ouma, 2007; Espinoza et al., 2017; Dias et al., 2018).

In E. tereticornis seedlings, root restriction reduced biomass without affecting partition, and growth reduction was not well related to lower net leaf photosynthesis (Campany et al., 2017). While in Acrocarpus fraxinifolius Wight \& Arn seedlings, stomatal conductance, net assimilation of carbon dioxide, transpiration, and quantum efficiency of photosystem II, depending on the fertilization they received, were reduced under smaller volumes of containers (Dias et al., 2018). In the same sense, Ouma (2007) observed that both the stomatal conductance and the net assimilation of carbon dioxide in $M$. indica seedlings were higher when produced in larger containers and more frequently irrigated. As also observed in T. esculenta seedlings in which the effect of reducing the volume of container was more effective, covering more variables, when the frequency of irrigation was lower (Table 2).
The reduction in the frequency of irrigation promotes lower water content in the substrate (Felippe et al., 2019), which may have been aggravated under a smaller volume of container, resulting in a water deficit, since between the containers with 1.30 and 0.75 $\mathrm{dm}^{3}$ there is a $42 \%$ reduction in the total volume and consequently in the capacity to retain moisture. Based on the available water of the substrate (field capacity - permanent wilting point) of $7.59 \%$, it is inferred that the larger container $\left(1.30 \mathrm{dm}^{3}\right)$ had the potential to store $99 \mathrm{~mL}$ while for the smaller one it was $57 \mathrm{~mL}$, causing greater fluctuations in water availability and probably making the seedlings more subject to water stress.

\section{Conclusions}

In the production of $T$. esculenta seedlings, daily irrigation is recommended instead of on alternate days, as it provides greater carboxylation efficiency and, consequently, net assimilation of $\mathrm{CO}_{2}$. $T$. esculenta seedlings are considered sensitive to salinity, and water with electrical conductivity lower than $1.0 \mathrm{dS} \mathrm{m}^{-1}$ should be used for irrigation. The polymer did not interfere in the present study. Containers with greater volumetric capacity (0.75 vs $\left.1.30 \mathrm{dm}^{3}\right)$ are indicated for the production of T. esculenta seedlings.

\section{Acknowledgments}

The present study was carried out with support from the Coordination for the Improvement of Higher Education Personnel (CAPES) and the National Council for Scientific and Technological Development (CNPq), 
through the granting of scholarships. We also thank the company Hydroplan-EB ${ }^{\circledR}$ for supplying the polymer.

\section{References}

Alves, E.U., Silva, K. B., Gonçalves, E. P., Cardoso, E. A., \& Alves, A. U. (2009). Germinação e vigor de sementes de Talisia esculenta (St. Hil) Radlk em função de diferentes períodos de fermentação. Semina: Ciências Agrárias, 30(4), 761-770. doi: 10.5433/1679-0359.2009v30n4p761

Baker, N. R. (2008). Chlorophyll fluorescence: a probe of photosynthesis in vivo. Annual Review of Plant Biology, 59, 89113. doi: 10.1146/annurev.arplant.59. 032607.092759

Berry, J. A., \& Downton, W. J. S. (1982). Environmental regulation of photosynthesis. In U. Govindjee (Ed.), Photosynthesis: development, carbon metabolism, and plant productivity (pp. 263-343). New York, NY: Academic Press.

Bezerra, M. A. F., Pereira, W. E., Bezerra, F. T. C., Cavalcante, L. F. C., \& Medeiros, S. A. S. (2014). Água salina e nitrogênio na emergência e biomassa de mudas de maracujazeiro amarelo. Agropecuária Técnica, 35(1), 150-160. doi: 10.25066/ agrotec.v35i1.19920

Bezerra, M. A. F., Pereira, W. E., Bezerra, F. T. C., Cavalcante, L. F. C., \& Medeiros, S. A. S. (2019). Nitrogenasamitigator of saltstress in yellow passion fruit seedlings. Semina: Ciências Agrárias, 40(2), 611-622. doi: 10.5433/1679-0359.2019v40n2p611

Campany, C. E., Medlyn, B. E., \& Duursma, R. A. (2017). Reduced growth due to belowground sink limitation is not fully explained by reduced photosynthesis. Tree Physiology, 37(8), 1042-1054. doi: 10.1093/ treephys/tpx038

Cardoso, E. A., Alves, E. U., \& Alves, A. U. (2015). Qualidade de sementes de pitombeira em função do período e da temperatura de secagem. Semina: Ciências Agrárias, 36(1), 7-16. doi: 10.5433/1679-0359.20 $15 \mathrm{v} 36 \mathrm{n} 1 \mathrm{p} 7$

Cruz, J. L., Coelho, M. A., Fo., Coelho, E. F., \& Santos, A. A. (2017). Salinity reduces carbon assimilation and the harvest index of cassava plants (Manihot esculenta Crantz). Acta Scientiarum Agronomy, 39(4), 545-555. doi: 10.4025/ actasciagron.v39i4.32952

Dias, G. P., Rodrigues, A. A., Costa, A. M., Carlos, L., Vasconcelos, S. C., Fo., \& Batista, P. F. (2018). Morphological, anatomical and physiological characteristics of Acrocarpus fraxinifolius Wight \& Arn seedlings according to containers and fertilization. Cerne, 24(4), 430-438. doi: $10.1590 / 01047760201824042589$

Espinoza, S. E., Santelices, R. E., Cabrera, A. M., \& Magni, C. R. (2017). Interactive effects of water stress, container size and fertilizer on survival, gas exchange and morphological traits of Quillaja saponaria seedlings. Bosque, 38(2), 409-414. doi: 10.4067/S0717-92002017000200018

Fagundes, M. C. P., Camilo, S. S., Soares, B. C., Cruz, L. I. B., Moreira, R. A., \& Cruz, M. C. M. (2014). Hydrogel polymer in emergency and early growth of citrus rootstocks. African Journal of Agricultural Research, 9(5), 2681-2686. doi: 10.5897/ AJAR2014.8491 
Felippe, D., Navroski, M. C., Aguiar, N. S., Pereira, M. O., Moraes, C., \& Amaral, M. (2019). Crescimento, sobrevivência e trocas gasosas de mudas de Eucalyptus dunnii Maiden submetidas a regimes de irrigação e aplicação de hidrogel. Revista Forestal Mesoamericana Kurú, 17(40), 11-20. doi: 10.18845/rfmk.v17 i40.4902

Guarim, G., Neto, Guarim, V. L. M. S., \& Nascimento, N. P. O. (2003). Repertório botânico da"pitombeira" (Talisia esculenta (A. St.-Hil.) Radlk. - Sapindaceae). Acta Amazonica, 33(2), 237-242. doi: 10.15 90/1809-4392200332242

Lima, A. J., Neto, Cavalcante, L. F., Nunes, J. C., Souto, A. G. L., Bezerra, F. T. C., \& Cavalcante, A. G. (2018). Biometric variables and photosynthetic pigments in tamarind seedlings irrigated with saline water and biofertilizers. Semina: Ciências Agrárias, 39(5), 1909-1920. doi: 10.5433/1679-0359.2018v39n5p1909

Maguire, J. D. (1962). Speed of germination-aid in selection and evaluation for seedling emergence and vigor. Crop Science, 2(2), 176-177. doi: 10.2135/cropsci1962.0011 $183 \times 000200020033 x$

Melo, J. S., Fo., Véras, M. L. M., Alves, L. S., Silva, T. I., Gonçalves, A. C. M., \& Dias, T. J. (2017). Salinidade hídrica, biofertilizante bovino e cobertura vegetal morta na produção de mudas de pitombeira (Talisia esculenta). Revista Scientia Agraria, 19(3), 131-145. doi: 10.5380/rsa.v18i3.54307

Montgomery, D. G. (2017). Design and analysis of experiments. Hoboken, NJ: John Wiley \& Sons.

Moura, A. R., Nogueira, R. J. M. C., Silva, J. A. A., \& Lima, T. V. (2016). Relações hídricas e solutos orgânicos em plantas jovens de Jatropha curcas L. sob diferentes regimes hídricos. Ciência Florestal, 26(2), 345-354. doi: 10.5902/1980509822735

Nascimento, E. C., Neto, Bezerra, F. T. C., Bezerra, M. A. F., Pereira, W. E., Cavalcante, L. F., \& Oliveira, F. F. O. (2020). Allometryand morphophysiology of papaya seedlings in a substrate with polymer under irrigation with saline water. Comunicata Scientia, 11, e3339. doi: 10.14295/cs.v11i0.3339

Nascimento, H. H. C., Santos, C. A., Freira, C. S., Silva, M. A., \& Nogueira, R. J. M. C. (2015). Ajustamento osmótico em mudas de jatobá submetidas à salinidade em meio hidropônico. Revista Árvore, 39(4), 641-653. doi: 10.1590/0100-67622015 000400006

Navroski, M. C., Araujo, M. M., Fior, C. S., Cunha, F. S., Berghetti, A. L. P., \& Pereira, M. O. (2015). Uso dehidrogelpossibilita redução da irrigação e melhora o crescimento inicial de mudas de Eucalyptus dunnii Maiden. Scientia Forestalis, 43(106), 467476. Recuperado de https://www.ipef.br/ publicacoes/scientia/nr106/cap22.pdf

Novais, R. F., Neves, J. C. L., \& Barros, N. F. (1991). Ensaio em ambiente controlado. In A. J. de Oliveira, W. E. Garrido, J. D. de Araújo, \& S. Lourenço (Eds.), Métodos de pesquisa em fertilidade do solo (pp. 189253) Brasília, DF: EMBRAPA Informação Tecnológica.

Oliveira, F. I. F., Souto, A. G. L., Cavalcante, L. F., Medeiros, W. J. F., Bezerra, F. T. C., \& Bezerra, M. A. F. (2017). Quality of jackfruit seedlings under saline water stress and nitrogen fertilization. Semina: Ciências Agrárias, 38(4), 2337-2350. doi: 10.5433/1679-0359.2017v38n4Supl1 p2337 
Oliveira, F. S., Sá, F. V. S., Souto, L. S., Paiva, E. P., Oliveira, F. A., Araújo, E. B. G.,... Mesquita, E. F. (2016). Seedling of development and tolerance of eggplant cultivars under saline stress. African Journal of Agricultural Research, 11(26), 23102315. doi: 10.5897/AJAR2016.11245

Ouma, G. (2007). Effect of different container sizes and irrigation frequency on the morphological and physiological characteristics of mango (Mangifera indica) rootstock seedlings. International Journal of Botany, 3(3), 260-268. doi: 10.3923/ijb.2007.260.268

Ovalles, F. A., \& Collins, M. E. (1988). Variability of northwest Florida soils by principal componenta nalysis. Soil Sicence Society of America Journal, 52(5), 1430-1435. doi: 10.2136/sssaj1988.0361599500520005 $0042 x$

Rahneshan, Z., Nasibi, F., \& Moghadam, A. A. (2018). Effects of salinity stress on some growth, physiological, biochemical parameters and nutrients in two pistachio (Pistacia vera L.) rootstocks. Journal of Plant Interactions, 13(1), 73-82. doi: 10.1080/17429145.2018.1424355

Roháček, K. (2002). Chlorophyll fluorescence parameters: the definitions, photosynthetic meaning, and mutual relationships. Photosynthetica, 4O(1), 1329. doi: 10.1023/A:1020125719386

Sá, F. V. S., Brito, M. E. B., Ferreira, I. B., Antônio, P., Neto, Silva, L. A., \& Costa, F. B. (2015). Balanço de sais e crescimento inicial de mudas de pinheira (Annona squamosa L.) sob substratos irrigados com água salina. Irriga, 20(3), 544-556. doi: 10.15809/ irriga.2015v20n3p544
Santos, D. B., Chiomento, L. J. T., Bortoluzzi, E. C., \& Petry, C. (2021). Gourd (Lagenaria siceraria (Mol.) Standl) seedling production and transplanting in different containers. Brazilian Journal of Development, 7(3), 21502-21516. doi: 10. 34117/bjdv7n3-049

Shin, Y. K., Bhandari, S. R., Cho, M. C., \& Lee, J. G. (2020). Evaluation of chlorophyll fluorescence parameters and proline content in tomato seedlings grown under different salt stress conditions. Horticulture, Environment, and Biotechnology, 61, 433-443. doi: 10.1007/ s13580-020-00231-z

Silva, A. B. V., Costa, A. C., Pinho, E. K. C., \& Reis, R. G. E. (2020). Substrates and container volumes in the production of mangabeira seedlings (Hancornia speciosa Gomes). Revista Ciência Agrícola, 18(2), 7-14. doi: 10.28998/rca.v18i2.9730

Silva, A. R., Bezerra, F. T. C., Cavalcante, L. F., Pereira, W. E., Araújo, L. M., \& Bezerra, M. A. F. (2018a). Biomass of sugarapple seedlings under saline water irrigation in substrate with polymer. Revista Brasileira de Engenharia Agrícola e Ambiental, 22(9), 610-615. doi: 10.1590/1807-1929/ agriambi.v22 n9p610-615

Silva, A. R., Bezerra, F. T. C., Cavalcante, L. F., Pereira, W. E., Araújo, L. M., \& Bezerra, M. A. F. (2018b). Frequency of irrigation with saline water in sugar-apple seedlings produced on substrate with polymer. Revista Brasileira de Engenharia Agrícola e Ambiental, 22(12), 825-830. doi: 10. 1590/1807-1929/agriambi.v22n12 p825-830 
Silva, L. G. A., Jr., Gheyi, H. R., \& Medeiros, J. F. (1999). Composição química de águas do cristalino do Nordeste Brasileiro. Revista Brasileira de Engenharia Agrícola e Ambiental, 3(1), 11-17. doi: 10.1590/ 1807-1929/agriambi.v3n1p11-17

Taiz, L., Zeiger, E., Møller, I. M., \& Murphy, A. (2017). Fisiologia e desenvolvimento vegetal. Porto Alegre, RS: Artmed.
Zhao, H., Liang, H., Chu, Y., Sun, C., Wei, N., Yang, M., \& Zheng, C. (2019). Effects of salt stress on chlorophyll fluorescence and the antioxidant system in Ginkgo biloba L. seedlings. HortScience, 54(12), 21252133. doi: 10.21273/HORTSCI14432-19 
